\title{
My Front Row Seat Memoir V
}

\section{Further Encounters at The Greatest Show on EArth}

\author{
Henry J.M. Barnett
}

Can J Neurol Sci. 2011; 38: 220-224

\section{This next part of my memories will shift to some European places.}

In what proved to be a forlorn attempt to settle the issue of benefit or not for subjects with asymptomatic carotid artery stenosis, the indefatigable Andrew Nikolaides from England's St. Mary's Hospital raised funds to invite a group with an interest in the carotid arteries to go on two occasions to the beautiful island of Cyprus. We stayed at a resort hotel owned by a friend of Andrew's. They were leisurely gatherings as befitted the ambience of a Mediterranean isle. For me the interesting features of these visits were fourfold. First, despite the large volume of singularly unimpressive evidence favoring surgery in the presence of no symptoms there was still much debate and speculation. Second I was able to make the acquaintance of a hero of mine, "Felix" Eastcott who had single-handedly changed medical practice in stroke prevention by being the first to publish on the removal of a narrowed segment of a carotid artery in a symptomatic patient. Within a decade at least one million carotid surgical procedures had been done worldwide. My involvement is covered in Memoir II. ${ }^{1}$ Thirdly we were able to see a lot of the Greek ruins on the island and among other things to stand with Felix on the shore allegedly at the spot where the goddess Venus had risen naked from the waves. Alas there was no second coming!

Among the amenities of our hotel were tennis courts. There I became aware that our grandson Brian Drake was a proper terror at the net. Fortunately he agreed to partner with me! The final source of interest was the opportunity to take tea at a restaurant that straddled the Greek/Turkish UN Green Line watched over by peace-keeping (Canadian) soldiers sporting their blue bonnets. On a later meeting of this group we visited a newlybuilt medical research building constructed under Nikolaides' direction to straddle the national borders of Greek Cyprus and Turkish Cyprus. The focus of special interest so far has been in genetic research, developed and staffed by Cypriot and Turkish sponsors. Scientists can work together even in the face of political quarrels. They pursue both inter-racial and, dear to my heart, interdisciplinary projects.

\section{Family Freedom Tour of Eastern Europe}

Stalin and his fellow thugs kept an iron grip on Eastern Europe. During those horrible days I went a couple of times to East Berlin, leaving with a feeling of relief punctuated by the grim faces at Check-point Charlie and the beast-begotten wall at my back. Bullet-holes were visible where attempted escapees were murdered. I always left with a sense that I had escaped to civilization. We were in the midst of the struggle to complete our cerebral by-pass study and Murray Goldstein drew to my attention that two neurosurgeons in Hungary, one in Budapest and one in Pecs, were experts at this procedure. To recruit them I journeyed to both cities making the acquaintance of Emil Pastor (chief of the neurosurgical Institute in Budapest) and the Tibor Merei (the energetic man from Pecs). Together they became major contributors to the trial.

We had no participating surgeons in East Berlin or East Germany. But one November evening in 1990 Kay and I with two grandchildren watched the news. Like the rest of civilization we were spell-bound as a bulldozer pushed down a slab of the Wall from the Communist side. I knew at the time that I was expected for two separate commitments in Germany two weeks apart in the coming April and that these particular grandchildren had reached the obligatory age of 12 years thus both due a trip abroad with grandparents. Forthwith, that evening the Family Freedom Trip was planned. I have imprinted little of my German duties but will never forget several things of the Freedom Tour: 1. The East German soldier at Check-point Charlie whose counterpart had been rude and angry at earlier visits was smiling, exceedingly polite and called me "sir". He had less than the six visas I bespoke (the mothers of the two grandchildren had hitched a ride and now we were six!) because they were "closing today" he hoped we "wouldn't mind walking the half-mile to the Brandenburg Gate?" "Why yes, and may I take your picture?" (unthinkable on earlier visits). With that he came to the front of the previously hateful gate for the picture! Freedom was in the air. Three weeks later the Toronto papers had a photo of "Checkpoint Charlie" on a flat-bed truck, said by the caption to be on its way to a war museum. 2. Half-way to the Gate was a gaping hole in the wall as big as a truck and just beyond it an armored jeep bristling with automatic weapons. From it jumped an East German army Sergeant, who leaped unarmed through the hole, ran towards us but by his smile meant us no ill. He was still running when he pointed at Adrian Love, who was wearing a Toronto Maple Leaf sweatsuit and shouted: "You know Wayne Gretzky?" He spoke acceptable English as we walked him back

Received September 27, 2010. Final Revisions Submitted September 30, 2010. Correspondence to: Henry J.M. Barnett, (Professor Emeritus, University of Western Ontario), 14865 Concession 7, King City, Ontario, L7B 1K4, Canada. 
to the hole in the wall but all we could do was tell him of our civic pride in a hockey player who did his best and wish him a good new life free of the Russian tyrants. 3. We watched as an American tourist was using his mountaineer's hand pick-axe to take samples of the graffiti-pocked wall. With a broad smile he handed it to Stephanie Drake who proceeded to liberate chunks as souvenirs for all of us. 4 . The most dramatic event of this memorable day occurred at the Brandenburg Gate. We arrived on May 1,1991, two minutes before noon. I approached the visa booth and someone in the back of the room shouted "Closed" and I was waved away. As a big clock nearby struck 12, a platoon of West German soldiers appeared and hustled all the forbidding confusing jumble of barriers to the sides of the street. A great shout went up and without visas the six of us joined the hustling cheering mob 20-abreast into East Berlin. Later we learned that 400,000 passed into East Berlin that afternoon. By lucky chance we watched the final liberation of Europe from the Communist heel, and with family we were privileged to be at its central point. 5. The second leg of the Freedom Tour was by train to Prague. The city was unspoiled as Hitler had tricked Chamberlain into the belief that Czechoslovakia was his last demand and its occupation took place with little destruction. What was sacrificed instead were all its country's Jews and any tattered remnants of integrity in him or his henchmen. In the weeks before our arrival an uprising led at first by students had just thrown off the Russian yolk, the sequel to the infamous Yalta division of the world by the victors.

We stayed at a hotel in Wenceslas Square at the top of which a larger than life statue of a mounted King Wenceslas stands. At the bottom of Prague's square a statue of Lenin had been wrenched from its base and lay on the ground. All gardens lining the centre of the Square were rimmed by 18 inches of candle wax deposited over the shrubs for many nights in a row at about midnight for two or three weeks by the growing multitudes of candle-carrying protesters, leading eventually to freedom. On the second morning a replacement of Lenin's statue had been placed on a freshly-cemented slab. The figure was of the country's first President after WWI, hidden away during the occupation. A few initials of our grandchildren went into the wet pedestal on which the statue stands and may likely be seen today. By the end of the day the statue was encased in the largest pile of cut-flowers that I have ever seen, dropped by people who cleaned out the stock of all the florist shops and street flower vendors. They were grateful and when Havel was recognized at a stop-light a great shout went up and people followed his car a few blocks into the area of the Parliament. In a little alcove around the corner from the statue were sculpted the bronze and gilded hands and arms of two early student protesters who were dragged away to an unknown fate but were mute testimony to the bravery of European freedom-hungry students. The two existing republics of Slovenia and the Czech Republics are testimonial to the bloodless separation that countries can effect by referendum. The world continues to have terrible examples of blood-letting by following the opposite course.

My final Czech experience was pick-pocketing. I was in line at a restaurant when I felt movement in my pocket as a large gypsy lady was attempting to remove my empty leather glasses case, presuming it was my wallet. I shouted, knocked her arm and she quietly melted away. The next day she passed me on the street and we both smiled and nodded to each other. She was large but her dress was too large even for her. A convenient spot was there to hide stolen goods! 6. The final Freedom Tour stop was Budapest. The train was slow, late, hot, and without food. For reasons obscure we were often at full stop. The only redeeming feature of one lengthy stop was the song of a nightingale coming through the open window. Loiseax and Orgogozo had taught me the song in the woods near Bordeaux the year before.

The Bad Years for Hungary were over and the national gloom was replaced by a palpable buoyancy in the spirits of my colleagues. The photo of Lenin was gone from the office of the head of the Neurosurgical Institute. Our vehicle no longer had to come to a complete stop when a platoon or less of Soviet soldiers wished to cross a street. My friend and neurosurgeon Istvan Nyari could go at will to the British Embassy and read Time or The Economist without encountering note-taking Secret Service agents who previously had cautioned him by name as he emerged from thus enclave of reason. My neurological friend Guyla Gacs could become the entitled owner of a delightful cottage on a small island on the Danube. His talented daughter could play for us on Liszt's own piano in the Liszt Concert Hall. We were taken to the central plains area, the breeding grounds and preserve of Europe's largest and heaviest bird, the great bustard. The males puff themselves up in a comical but colorful fashion and each one is surrounded by a crowd of drab and unattractive females. The largest birds had the largest circles of females and seemed greedily waiting for yet more to join the ranks before they would perform their polygamous duties. In the bird world for the most part the females lack gorgeous colors possibly to be less conspicuous on the nest and less obvious to predators. How fortunate for today's vain males that the resplendent men's dress of Elizabethan times has nearly vanished. As I was brooding about this unique bird behavior I was amused that there kept coming across the plain the loud voice of a European Cuckoo, who mocks his name more clearly than our two cuckoo varieties in Canada.

The high point of the Freedom Tour in Hungary was the invitation to the Distinguished Visitors' Gallery of Parliament. It and the ancient Senate Building on the Danube had been reparable and were now in use. Saintagoti (now the VicePremier) had authorized Hungary's participation in the Bypass Study and once in the Bad Days had hosted, as chairman of their Medical Research Council, a dinner for Europe's By-Pass collaborators. He invited us to go with an interpreter (his own parliamentary assistant) to question period on Day 4 of the newly-elected Parliament. All seats were full, the air was electric and all questions thoughtfully answered. Kay and I noted that a number of the questions were coming from the side of the House opposite to us. Even though they were casually dressed (sweatshirts and even a few tank-tops), mostly in jeans, mostly long-haired and some unshaven, an equal number were women in jeans or long peasant-style dresses, it pleased us to hear that they spoke quietly and their questions to the government and its Cabinet members were said, by our interpreter, to be good ones and were fully answered. Kay and I spoke almost simultaneously to Mr. Kovitz: "Who in the world are these people?" "Did you not guess? They are the Freedom Party members. They are the ones who first took to the streets. Without them we probably would not be here!" 
Both Saintagoti and Guyla (whose wife and only child surprisingly arrived in Canada with visas in the bad old days and were staying with us at the time) were offered academic positions in London, Canada. They both agonized and turned them down saying more or less the same thing: Paraphrase: "When liberty is restored what will happen to my country if the educated all have left?" They gambled and won. Brave souls! Two decades earlier tanks greeted protesters and Canada spared lives and careers by accepting the rebellious. Gorbachev ushered in the new era, the fruits of which we were privileged to sample first-hand on our Family Freedom Tour.

\section{Here I will insert some Pacific memories}

Australia is a country best described as unique and as having it all. If it were closer to Europe and North America there is little doubt that much of its beauty and its grandeur would be devastated by now: coral reefs, tropical jungles, deserts, coniferous forests, wine-growing areas, challenging mountains - to say nothing of its wedge-tailed eagles, kangaroos, wallabys, wild feral camels and koalas. The people are optimistic, energetic, good friends and good scientists. Because they were heavily committed to most of my trials I have lost track of the number of times I have been there but my memory retains the long hours needed to go and come: always great to get there and always sorry to leave. Three good budding neurologists have come from there to work with me, and they have been refreshing and hard-working young men. Several academic centres were contributors to my major trials. One famous evening at a dinner in Sydney when we were recruiting centres to join in my last endarterectomy trial, my host, Geoff Donnan, asked a senior vascular surgeon to welcome me. He responded by averring that he was pleased to welcome me as a guest in his country but the assembled group should know that since my last visit to Australia, when I had cautioned against the indiscriminate use of endarterectomy for patients with narrowed arteries but no symptoms, I was, he said, "responsible" for strokes and deaths in many Australians. Wow! An immediate hush interrupted the dinner. Even the waitresses were observed to pause. It was almost as if they did not know how to function in the presence of a murderer. The accuser/welcomer then went on to mutter something to the effect that I had reported my anti-surgical views to several Australian newspapers and as a sequel to the reports his referral practice had fallen off. There was substantial evidence of my guilt: strokes or deaths had occurred in some who had not been given CE. At this awkward point, Heather Meldrum, my quick-thinking Director of our NIH studies, broke in and stated that we never intentionally published any of our work in newspapers but favored peer-reviewed medical journals. Our main results papers, including one on the risk of stroke in our study patients who had asymptomatic disease on the "other side" were generally in the NEJM. The invitation to the press to attend my lecture came from my Australian hosts. The meal and the discussion continued with calming words from the unflappable and wise Geoffrey Donnan (now Editor-in-Chief of the International Journal of Stroke). At the end of the day, the recalcitrant surgeon said he would sign up for this trial of symptomatic carotid patients. He made no contributions. We were not studying his customary target: the asymptomatic individual.
Australia is replete with natural and man-made wonders: The Great Barrier Coral Reef, the northern tropical shores with aggressive and man-eating crocodiles, Kakado National Park, Darwin with its scars, memorabilia and graveyards from the aborted Japanese invasion of 1943. The enemy plan had been totally frustrated by the converse of Pearl Harbor's: the destruction at Midway of the huge Japanese navy attack force and troop-carrying ships that had been detected by the breaking of the allegedly impenetrable shared Nazi secret communications code by "Intrepid", a Canadian mathematical genius.

The tidy east coast town of Perth harbors the first yacht that wrestled the international Yachting cup from its century-old domination by America and in a different context harbors as well two of the world's best stroke neurologists, Graham Hankey and William Carroll. At the south-east corner of Australia is Tasmania with its northern Ontario or Maine type of climate and coniferous forests. East of it are the carefully preserved remains of Britain's equivalent of The Soviet Gulag and America's Guantanamo: the infamous penal colony portrayed in "The Fatal Shore". The crimes leading to transportation varied from repeated minor stealing to another large group who held membership in or expressed sympathy with one of the Irish organization unfavorable to Britain's occupation of their land. The least submissive or rebellious prisoners were taken offshore to Norfolk Island with its more sadistic custodians. Among the successive governors of the penal institution was Sir John Franklin, who disappeared seeking an Arctic Northwest Passage. There is no certain record of his being as sadistic as some of his predecessors and successors, nor yet any assurance that he was more compassionate.

The NASCET saga and the dawn ascent of Ayer's Rock by most of our team has been described in Memoir III $^{2}$. Three times I have indulged myself by visiting the nearby sewage lagoons of Alice Springs. Being a watery oasis albeit of non-sparkling sewage fluid in the central Desert, the lagoons are wintering grounds for remarkably large numbers of waterfowl including flocks of the spectacular black swan. There is one big old dead tree in the centre of the lagoon. Each time I have visited it has harbored a peregrine falcon, patiently surveying his smorgasbord. On each visit he has declared "lunch time" and helped himself to a whistling tree duck or a pintail and then has settled back to eat it on his snag and then to wait until the urge to kill and eat returns. His prey has no chance. He swoops by, scares up the flock, makes his decision, chooses his victim sets his wings for a dive, and picks his meal out of the air. His stoops are inescapable and have been timed at $180 \mathrm{mph}$.

Off Australia's south coast lies the unspoiled Kangaroo Island where koalas and wallabies are abundant. Off New Zealand's south coast lies Stewart Island, a nature preserve where flightless birds such as rails and kiwis remain numerous. Sea lions go ashore and into the forests here to have their young. Albatross are numerous between the South Island and Stewart Island. We watched them seemingly oblivious to the storm-tossed seas that we were enduring in the ferryboat going back to the mainland. The albatross colony near Dunedin in New Zealand was a relished plan on our only visit to this country. There was, on the day of our visit to the South Island, no breath of wind at all. This total calm grounded the colony and as near-approach is protectively forbidden we could not even watch them at their 
nests. Three days later the proprietor of the only lodge on Stewart Island, who had promised a visit on the south side of Stewart Island to the largest intact kiwi colony, had to cancel this maritime visit due to raging seas and hurricane-force winds. In all parts of the world nature is in charge of human agendas.

In Alice Springs, my former Australian stroke research Fellow, Peter Gates arranged for us to meet with a remarkable resident of Alice Springs. Ian Blevin had moved from his family's farm in Zimbabwe to this remote town in central Australia where he was running a guided-tour company. He knew in intimate detail all birds and vegetation of this arid land and yet formerly (at the end of his schooling) had been a Major in a Ghurka Regiment (an unusual past record for a nature-loving person). Learning that the next stop was to recruit Johannesburg into NASCET, Ian persuaded Heather and me to go with him en route plus a Zimbabwean native friend as an extra guide and paddler, on a six day canoe trip on the Zambezi River, that starts at the Victoria Falls and separates Zimbabwe from Zambia. As Ian knew it was a time of the year when there was not a strong current so that paddling was simple, despite the fact that our two Peterborough canoes were quite loaded with camping gear and in each canoe a loaded rifle. For me it was a nature-lover's feast. Our first experience of a family of hippos was when Ian in the bow of my canoe stood with one foot on each gunwale to make absolutely certain that he had identified the bull of the pod and making certain that we were not between him and the rest. Had that been the case our canoe would have been attacked and, as we later learned, the crocodiles would sweep in quickly and eat us as they did a German couple earlier in the year. Crocs and hippos make a good team, the hippos are vegetarians but posses a very protective instinct for their young and their concubines in the pod. The crocodile's main diet was not humans but was fish. We too ate much fish (Talapia) that we purchased from Zambian natives fishing near shore in dug-out canoes. The gunwales of these craft were surprisingly low to the water but the air and the water were generally quite still.

We made our nightly camps on islands and were comforted by this knowledge as we nightly heard lions roar and hyenas laugh. Owls, new and strange to me, were commonly heard. Ian made sure that each of us were protected by individual "tents" of mosquito-proof netting and, of course, we faithfully took antimalarial drugs. One particular event made me wonder about the safety of our island campsites. I awoke to much scrambling and snorting at the shore about 200 feet from my mosquito net. Quickly Ian woke up and in his powerful flashlight we could see a baby hippo being unsuccessfully chased by a large crocodile. Heather remained peacefully asleep between me, Ian and the shore. She found it implausible in the morning that this savage chase had occurred within no more than 100 feet from where she lay in innocent slumber. Two restrictions applied to the water in Zimbabwe. In the use of paddles on the Zambezi we were warned to take a shorter grip than customary. It was reputed that dipping the right hand in the water held out a temptation to the lurking crocodiles. The warning on the Blevin farm was to expose no skin to the lake water there as what lurked was again not visible but could be deadly: the parasite causing schistosomiasis (also known as bilharzia or snail fever, as it survives in fresh water snails). We went for a small trip on this lake where we saw nesting Egyptian Geese similar to those painted on the walls of the Pharaoh's tombs in Egypt. Despite earlier unsuccessful attempts at gun-point by the tyrannical ruler of the land (Mugabe) to force Ian's family to give up their successful farm when we were there, his family (parents and older brother) remained in the original farm-house (from colonial Rhodesia days) and while we visited they celebrated an award for a most successful crop. I have not been able to trace Ian Blevin and am uncertain of the fate of his embattled family. It is hard not to believe the worst.

We left for South Africa by air from the capital city of Harare. Not long afterwards it was the site of post-election rioting and slaughter. One can assume that the present farmers' and artists' markets in the centre of town are there no longer. Tourists will be absent as will the sidewalks covered with beautifully carved wild beasts of the region. To my right at the moment is a striking carving of a giraffe nursing its baby. The world and its religious zealots helped the colonial powers create Zimbabwe, its excessive uneducated population, leaving behind a bitterness that will persist for generations. When justifiable punishment is given in the Hague to Mugabe, financial penalties could be shared by those who simply took the area from its historical peoples and to the religious leaders, local and imported whose twisted views continue to proscribe birth control measures that would make it a governable place, free of overpopulation, treatable and preventable diseases.

I must admit that putting South Africa into NASCET was an exciting prospect. Probably, had we reflected sufficiently ahead of time about the racial predilection for blacks to have intracranial atheroma instead of the Caucasian predilection to neck lesions we would have denied their application to join our team and spared ourselves the embarrassment of a mere handful of randomizations from our one African centre. It gave us an opportunity to visit their black-dominated Houses of Parliament and Senate. The connecting hallway between the two chambers once held the portraits of all the Apartheid leaders. They are now in long-term storage and the sole portrait in this long hallway is of Helen Suzman. In the terminal pre-Mandela government she was the sole remaining member of the opposition party. A brave woman who was outspoken both in and out of parliament, sufficiently prominent and widely respected that she ventured to speak where all others felt cowed into silence. Carol Kaufmann, an equally brave person, was an active white member of the antiApartheid forces, showed us about parliament (in recession) and I had the opportunity to sit in Nelson Mandela's primeministerial chair. She was well acquainted with him, one of my greatest heroes, and he knew that she had been instrumental on separate occasions in smuggling in her own car (sometimes covered by dirty laundry, sometimes in the trunk) three of his female supporters across borders to safety when their liberty was being threatened.

As an indulgence, and with the Johannesburg team, we drove to the Kruger National Park on the eastern edge of the country. It is a great game-preserve but lacks the huge herds of the Serengeti or Botswana. We stayed in cottages but were able to recognize that lions were roaring nearby, that hyenas were plentiful and "laughing" most of the night and we could pick out the occasional growl of hippopotami. My best memory of Kruger was gleaned in Johannesburg. At dinner in an exclusive club, an enclave of privileged whites, discussion ranged over the 
great changes that Mandela's release had wrought. Our host, an outspoken surgical colleague, gloomily predicted that grave economic disasters surely lay ahead "threatening our way of life with untrained black men in charge; we should never have succumbed to outside pressures." An attractive woman, his wife, sitting beside me spoke up determinedly: "Maybe you're right, give them a chance. At least now we can hold up our heads to the world!" It was good to hear her, especially knowing that she was the grand-daughter of Kruger, the country's first leader as they emerged from the colonial era -- only years later to become a non-colonial country that slipped into apartheid.

I will now conclude Pacific memories by recounting tales of two very different islands. On one of our Australian visits we went to New Zealand for a few days. Near Dunedin, in the South Island, is a nesting colony of albatross, high on my birding wishlist. We drove there to the appointed viewing spot with a large hill between us and the very closely protected colony. The wind dropped to nothing and any albatross with their ten foot wingspan were unable to fly in or out. Nature flatly thwarted our wishes. The next day we took the ferry to the small island south of the South Island: Stewart Island has one lodge, where we stayed. Divers went out one afternoon and we learned what "fresh scallops" are about. The whole island is a nature reserve and refuge and the last redoubt of several species of flightless birds, rails in the marshes and forests, but also the rare but very shy and flightless kiwi. Our lodge manager offered a plan to take us on our last evening by boat around to the south shore of the refuge where the majority of the kiwis remain. Mid-afternoon a wild gale blew up and our excursion was impossible. For the second time in one week Nature's dominance of our world was thrown at us and our plans.

The other island to recall was Guam in mid-Pacific. We stopped there after an Australian visit. A former resident and friend from Toronto days lives and works there for the US Public Health Service. From his porch we could look down the beach to the obelisk erected to Magellan commemorating the first land he stood upon after passing through the straits at the tip of South America that bear his name. His famous trip, the first ever to circle the globe, made it clear forever that the earth was round.
The natives of Guam eat the fruit bats and a toxin in their flesh is believed to be the cause of a common and falsely considered to be a unique "familial" form of Parkinson disease with serious dementia. Some of those afflicted add a variant of ALS to this burden of "degenerative disease" and as my friend and former resident, John Steele, pointed out there has been additionally a tendency to progressive supranuclear palsy in a substantial number of them (this PSNP was originally described by Steele and Richardson in Toronto). This curious disorder was overlooked in Guam by a large team of NIH-funded epidemiologists, not prone to the meticulous form of neurological examination practiced by Steele. As he demonstrated to me it is possible for an individual to be afflicted with some features of all four of these conditions or to have only one of the four in its more standard ("pure") form.

I was proud of the diligence of my former resident in this remote island. When we visited the small sanctuary north of Guam to see a rare booby and a very local species of crow, we were faced with an oversold flight and "no more seats" on the return and final flight of the day. The accommodations offered for the night were hard benches and lavatory facilities. When the small airline officials who were bumping us became aware that we were John Steele and special guests of Our Dr. John Steele, a special plane and pilots were produced with apologies to us. Such is the esteem in which John is held in Guam and environs as he researches and cares for the victims of the dreaded disease that they have faced for decades. There remain some questions about this disorder and the research must be accepted as "work in progress". Coincident with a warning about the association with eating the meat of "flying foxes" this disorder has been of diminishing occurrence.

\section{REFERENCES}

1. Barnett HJM. Personal reflections from a front-row seat at the greatest show on earth- Part II (stroke research commentary). Stroke. 2009; 40:e53-65.

2. Barnett HJM. More reflections on life; Part III. Can J Neurol Sci. 2010;37:160-6. 